\title{
Distinct clinical features and prognostic factors of hepatitis $C$ virus-associated non-Hodgkin's lymphoma: a systematic review and meta-analysis
}

Minyue Zhang ${ }^{1,3+}{ }^{\text {, Fei Gao }}{ }^{2+}$, Ling Peng ${ }^{3}$, Lijing Shen ${ }^{1}$, Peng Zhao ${ }^{2}$, Beiwen Ni ${ }^{1}$, Jian Hou ${ }^{1 *}$ and Honghui Huang ${ }^{1 *}$ (D)

\begin{abstract}
Background: Increasing evidence suggests that hepatitis C virus (HCV) infection is associated with non-Hodgkin's lymphoma (NHL). However, no clear consensus has been reached about the clinical features and effective treatment of HCV-associated NHL patients. We therefore performed a systematic review and meta-analysis to explore the clinical characteristics and effectiveness of antiviral treatment or rituximab administration among NHL patients with HCV infection.

Methods: Eight electronic databases, including PubMed, OVID, EMBASE, Cochrane Library, ClinicalTrials, WANFANG, CNKI, and VIP, were searched for eligible studies up to July 31, 2021. The hazard ratio (HR) or odds ratio (OR) corresponding to the $95 \%$ confidence interval (Cl) was calculated to estimate the outcomes. Publication bias was assessed by Egger's and Begg's tests. Statistical analysis was performed with RevMan 5.4 software and Stata version 15.

Results: There were 27 shortlisted articles out of a total of 13,368 NHL patients included in the current meta-analysis. Our results demonstrated that NHL patients with HCV infection had a significantly shorter overall survival (OS: HR 1.89; $95 \% \mathrm{Cl} 1.42-2.51, \mathrm{P}<0.0001$ ) and progression-free survival (PFS: HR 1.58; 95\% Cl 1.26-1.98, $\mathrm{P}<0.0001$ ), a lower overall response rate (ORR: OR $0.58,95 \% \mathrm{Cl} 0.46-0.73, \mathrm{P}<0.00001)$ and a higher incidence of hepatic dysfunction during chemotherapy (OR 5.96; 95\% Cl 2.61-13.62, P<0.0001) than NHL patients without HCV infection. HCV-positive NHL patients exhibited an advanced disease stage, an elevated level of LDH, a high-intermediate and high IPI/FLIPI risk as well as a higher incidence of spleen and liver involvement. Moreover, antiviral treatment prolonged survival (OS: HR 0.38; 95\% Cl 0.24-0.60, P<0.0001), reduced disease progression [PFS/DFS (disease-free survival): HR 0.63; 95\% Cl $0.46-0.86, P=0.003$ ] and reinforced the treatment response (ORR: OR 2.62; 95\% Cl 1.34-5.11, $P=0.005$ ) among the HCV-infected NHL patients. Finally, rituximab administration was associated with a favourable OS, while liver cirrhosis and low levels of albumin predicted a poor OS for HCV-positive NHL patients.
\end{abstract}

\footnotetext{
*Correspondence: houjian@renji.com; huanghonghui@renji.com

${ }^{\dagger}$ Minyue Zhang and Fei Gao-Co-first authors, contributed equally to this

work

${ }^{1}$ Division of Hematology, Renji Hospital, School of Medicine, Shanghai

Jiaotong University, Shanghai 200127, China

Full list of author information is available at the end of the article
}

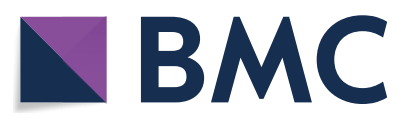

(c) The Author(s) 2021. Open Access This article is licensed under a Creative Commons Attribution 4.0 International License, which permits use, sharing, adaptation, distribution and reproduction in any medium or format, as long as you give appropriate credit to the original author(s) and the source, provide a link to the Creative Commons licence, and indicate if changes were made. The images or other third party material in this article are included in the article's Creative Commons licence, unless indicated otherwise in a credit line to the material. If material is not included in the article's Creative Commons licence and your intended use is not permitted by statutory regulation or exceeds the permitted use, you will need to obtain permission directly from the copyright holder. To view a copy of this licence, visit http://creativecommons.org/licenses/by/4.0/. The Creative Commons Public Domain Dedication waiver (http://creativeco mmons.org/publicdomain/zero/1.0/) applies to the data made available in this article, unless otherwise stated in a credit line to the data. 
Conclusions: The current study provided compelling evidence about an inferior prognosis and distinct clinical characteristics among HCV-associated NHL patients. Antiviral treatment and rituximab-containing regimens were shown to be efficacious in improving the clinical outcomes of NHL patients with HCV infection.

Keywords: Non-Hodgkin's lymphoma, HCV infection, Prognosis, Antiviral treatment, Meta-analysis

\section{Background}

Non-Hodgkin's lymphoma (NHL) is a group of lymphoid malignancies with high heterogeneity. It can be classified into B-cell, T-cell, and natural killer (NK)-cell lymphoma. Increasing amounts of evidence has shown that pathogen infection contributes to the pathogenesis of different subtypes of lymphoma, such as Epstein-Barr virus (EBV) in Hodgkin disease or Burkitt's lymphoma, human T-cell leukaemia virus type 1 in adult $\mathrm{T}$ cell leukaemia and lymphoma, and Helicobacter pylori in gastric mucosaassociated lymphoid tissue [1-3]. According to the 2016 revision of the World Health Organization (WHO) classification of lymphoid neoplasms, two subtypes of NHL associated with specific viral infection, EBV-positive diffuse large B-cell lymphoma (DLBCL) and human herpesvirus type-8 (HHV-8)-positive DLBCL, have been classified as separate subtypes of DLBCL [4]. These new categories strongly support the hypothesis that NHL patients with specific infections display distinct clinical manifestations and prognoses.

Recently, hepatitis C virus (HCV) was found in peripheral blood mononuclear cells and lymph nodes $[5,6]$, and hepatitis C NS3 protein could be detected in tumour cells from patients with $\mathrm{HCV}$-associated B-cell lymphoma [7], suggesting that $\mathrm{HCV}$ is also lymphotropic. In addition, a meta-analysis provided quantitative evidence that HCV infection could lead to a 2.5 -fold increased risk of developing NHL [8]. Nevertheless, the clinical characteristics and prognosis of $\mathrm{HCV}$-associated lymphoma are still undefined.

Increasing clinical attention has been focused on the association of $\mathrm{HCV}$ infection and the clinical outcomes of NHL patients. However, the results are still inconsistent based on the existing retrospective studies with small sample sizes [9-18]. Hosry et al. [17] found that HCVassociated DLBCL had unique clinical features and poor outcomes. However, other studies $[14,18]$ have shown that $\mathrm{HCV}$ infection is not associated with NHL patient survival. In addition, an increasing number of studies have explored the survival benefit of antiviral treatment or rituximab-containing chemotherapy in NHL patients with $\mathrm{HCV}$ infection, yet the results are controversial [15, 19-22]. In view of the limitations of previous studies, we performed a systematic review and meta-analysis aiming to evaluate the clinical features and prognostic factors of HCV-associated NHL patients. Moreover, the effect of antiviral treatment and rituximab administration on NHL patients with $\mathrm{HCV}$ infection was also investigated in the current study.

\section{Methods \\ Identification of relevant studies}

To identify all studies that explored the impact of $\mathrm{HCV}$ infection on the clinical outcomes of NHL patients or the effect of antiviral treatment and rituximab administration on NHL patients with HCV infection, literature searches of the PubMed, EMBASE, OVID, Cochrane Central Register of Controlled Trials (CENTRAL/CCTR) and ClinicalTrials (https://clinicaltrials.gov) databases were carried out up to July 31,2021 . The strategies of literature search were summarized in Additional file 1: Table S1. Additionally, literature searches were also performed in three Chinese databases, including WANFANG (http:// www.wanfangdata.com), CNKI (https://www.cnki.net) and VIP (http://www.cqvip.com), with the same search strategies as those for English databases. References from the retrieved studies, meeting abstracts, relevant metaanalyses and systematic reviews were also screened. Case reports, editorials and review articles were excluded. When a publication overlapped with other publications of the same trial, only the article with more details or the most recent article was retained.

\section{Selection criteria and study outcomes}

The studies included in the meta-analysis needed to satisfy all of the following criteria: (1) the study population was NHL patients. NHL was diagnosed by cytological examination or pathological examination according to the WHO Classification of Tumors of Hematopoietic and Lymphoid Tissues [4]; (2) HCV infection was defined as the detectable HCV-RNA or HCV antibody; and (3) The study focusing on the impact of HCV infection on NHL. The study population consisted of two groups: NHL patients with and without HCV infection. The clinical features or survivals between the two groups of patients were compared; or (4) The study focusing on the effect of antiviral or rituximab treatment on $\mathrm{HCV}$-associated NHL. The study population consisted of two groups: $\mathrm{HCV}$-infected NHL patients receiving and not receiving antiviral/rituximab treatment. The treatment response and clinical prognosis between the two groups of patients were analysed. The exclusion criteria were as follows: (1) 
patients co-infected with human immunodeficiency virus (HIV); (2) patients with post-transplant lymphoproliferative disorder; and (3) patient numbers less than or equal to ten in any study group. When the relevant data were not reported in the paper, we contacted the author to obtain the relevant information by e-mail or telephone.

The primary outcomes assessed the impact of $\mathrm{HCV}$ infection on the NHL patients' prognoses, including overall survival (OS) and disease progression [progression-free survival (PFS)/disease-free survival (DFS)]. The other outcomes measured the treatment response [overall response rate (ORR)] and the clinical characteristics of NHL patients with $\mathrm{HCV}$ infection, including the age of disease onset ( $<60$ years old); the presence of B symptoms; advanced disease stage (Ann Arbor staging III/IV); involvement of the spleen, liver and bone marrow; elevated LDH level; high-intermediate and high IPI/FLIPI risk; and the incidence of hepatic dysfunction during chemotherapy. Furthermore, the effect of antiviral therapy or rituximab administration as well as liver-related prognostic factors for $\mathrm{HCV}$-positive NHL patients was also investigated. Since PFS and DFS are similar outcomes reflecting disease progression, we pooled PFS and DFS for analysis in the current study.

\section{Data extraction}

Two reviewers (Gao F and Peng L) independently extracted the data and outcomes using an electronic standardized form. The following information from each study was summarized: (1) first author, (2) year of publication, (3) country, (4) subtypes of NHL, (5) number of patients with and without HCV infection, (6) number of HCV-positive NHL patients receiving and not receiving antiviral/rituximab treatment, (7) anti-lymphoma therapeutic regimens, (8) antivirus treatment regimens, and (9) patient characteristics. Any discrepancies between the two reviewers were resolved by an additional investigator, Zhang $\mathrm{M}$.

\section{Quality assessment}

The Newcastle-Ottawa Quality Assessment Scale (NOS) was adopted to assess the methodological quality of the included studies [23]. The following three items were evaluated: (1) patient selection, (2) comparability of the intervention and observation groups, and (3) assessments of the outcomes.

\section{Statistical analysis}

The hazard ratio (HR) corresponding to the 95\% confidence interval (CI) was used to assess OS and PFS/DFS. If both the univariate and multivariate analysis results were reported in the included study, the latter was used in the meta-analysis. If the HRs and 95\% CIs were not available from the original article, Kaplan-Meier curves of the included studies were reanalysed by Engauge digitizer software. The HRs and 95\% CIs were indirectly calculated from the Kaplan-Meier curves using Tierney's methods [24]. Odds ratios (ORs) corresponding to the 95\% CIs were calculated to estimate the other outcomes. Publication bias was assessed by Egger and Begg's tests. When the outcome was assessed by fewer than five included studies, publication bias tests were not performed. The methods of the meta-analyses and publication bias tests have been reported in our previous publications [25-28]. Statistical analysis was performed with ReviewManager 5.4 software (The Cochrane Collaboration, Oxford, UK) and Stata version 15 (Stata Corp, College Station, Texas, USA). All P-values were two-sided, and a P-value of $<0.05$ was considered significant.

\section{Results}

\section{Characteristics of the eligible studies}

After the comprehensive literature search, 3987 articles were identified as potentially relevant publications. Upon further evaluation of the full text, 21 articles were excluded. Thus, 27 articles (29 studies) [9-22, 29-41] with a total of 13,368 NHL patients, including 3063 patients with $\mathrm{HCV}$ infection and 10,305 patients without $\mathrm{HCV}$ infection, fulfilled the inclusion criteria and were included in the current meta-analysis (Fig. 1). The characteristics of the included articles are summarized in Table 1. The articles were published between 1997 and 2020 with sample sizes ranging from 58 to 5586 . The majority of the studies were conducted in Italy $(n=11)$, Japan $(\mathrm{n}=4)$, Egypt $(\mathrm{n}=3)$, China $(\mathrm{n}=2)$, France $(\mathrm{n}=2)$ and the United States $(n=2)$. The other articles consisted of a single study each conducted in Russia, Korea, and Spain. Among the included articles, 14 articles focused on DLBCL, two articles on follicular lymphoma and two articles on marginal zone lymphoma. In addition to the aforementioned lymphoma subtypes, the patients in 9 articles had more than two subtypes of NHL. With regard to the methodological quality, most of the included articles had reliable quality, as indicated by NOS scores $\geq 6$ points, except for 2 articles [30,38] with NOS scores of 5 points (Additional file 2: Table S2).

\section{The impact of $\mathrm{HCV}$ infection on NHL patients' prognosis}

Among all 29 studies, 15 studies were available for the analyses of OS. Due to obvious heterogeneity among these studies $\left(\mathrm{I}^{2}=47 \%, \mathrm{P}_{\text {heterogeneity }}=0.02\right)$, a randomeffects model was used to pool all HRs and their 95\% CIs. Meta-analysis revealed that HCV-positive patients had significantly worse OS than HCV-negative patients (HR 1.89; 95\% CI 1.42-2.51, $\mathrm{P}<0.0001$; Fig. 2a).

A total of 8 studies were eligible for the assessment of PFS. A fixed-effects model was used to calculate 


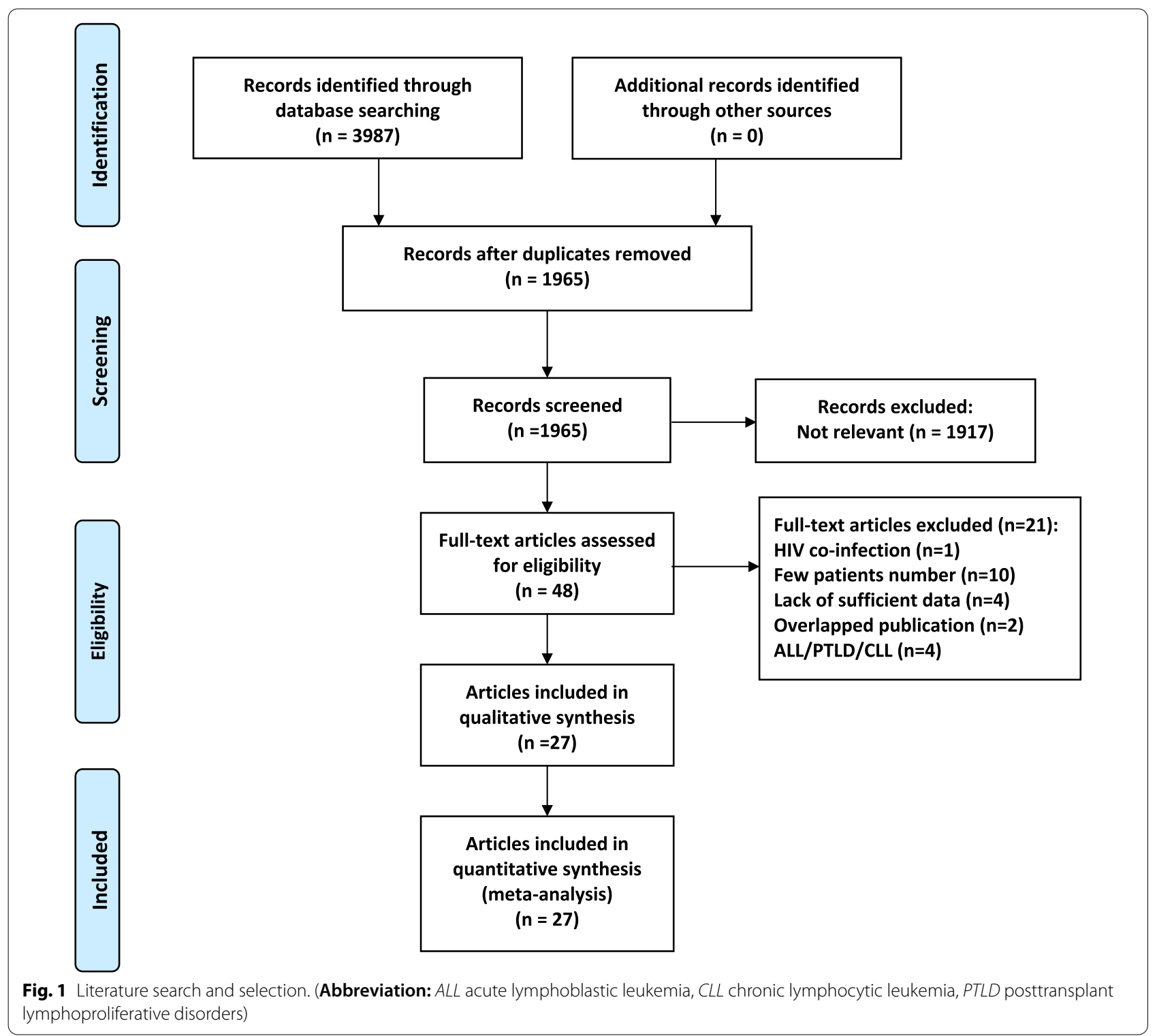

the results, as there was no heterogeneity among the included studies $\left(\mathrm{I}^{2}=0 \%, \mathrm{P}_{\text {heterogeneity }}=0.59\right)$. The results demonstrated that patients with HCV infection showed a significantly shortened PFS compared with patients without HCV infection (HR 1.58; 95\% CI 1.26-1.98, $\mathrm{P}<0.0001$; Fig. 2b).

\section{$\mathrm{HCV}$ infection and treatment response}

Eleven studies were identified to assess the ORR between NHL patients with and without HCV infection. The OR and $95 \% \mathrm{CI}$ of the ORR were pooled by using a fixedeffects model, as the heterogeneity tests suggested no significant heterogeneity $\left(\mathrm{I}^{2}=28 \%, \mathrm{P}_{\text {heterogeneity }}=0.18\right)$. The combined results showed that the ORR of HCV-positive
NHL patients was significantly lower than that of $\mathrm{HCV}$ negative NHL patients (OR 0.58, 95\% CI 0.46-0.73, $\mathrm{P}<0.00001$, Fig. 3).

\section{$\mathrm{HCV}$ infection and hepatic dysfunction during chemotherapy}

In total, 7 studies including 2095 participants (DLBCL patients) were eligible for the analysis of this outcome by the random-effects model $\left(\mathrm{I}^{2}=78 \%\right.$, $\mathrm{P}_{\text {heterogeneity }}=0.0001$ ). As shown in Fig. 4, a higher incidence of hepatic dysfunction during chemotherapy was observed in $\mathrm{HCV}$-infected patients than in HCV-noninfected patients (OR 5.96; 95\% CI 2.61-13.62, $\mathrm{P}<0.0001$ ). 


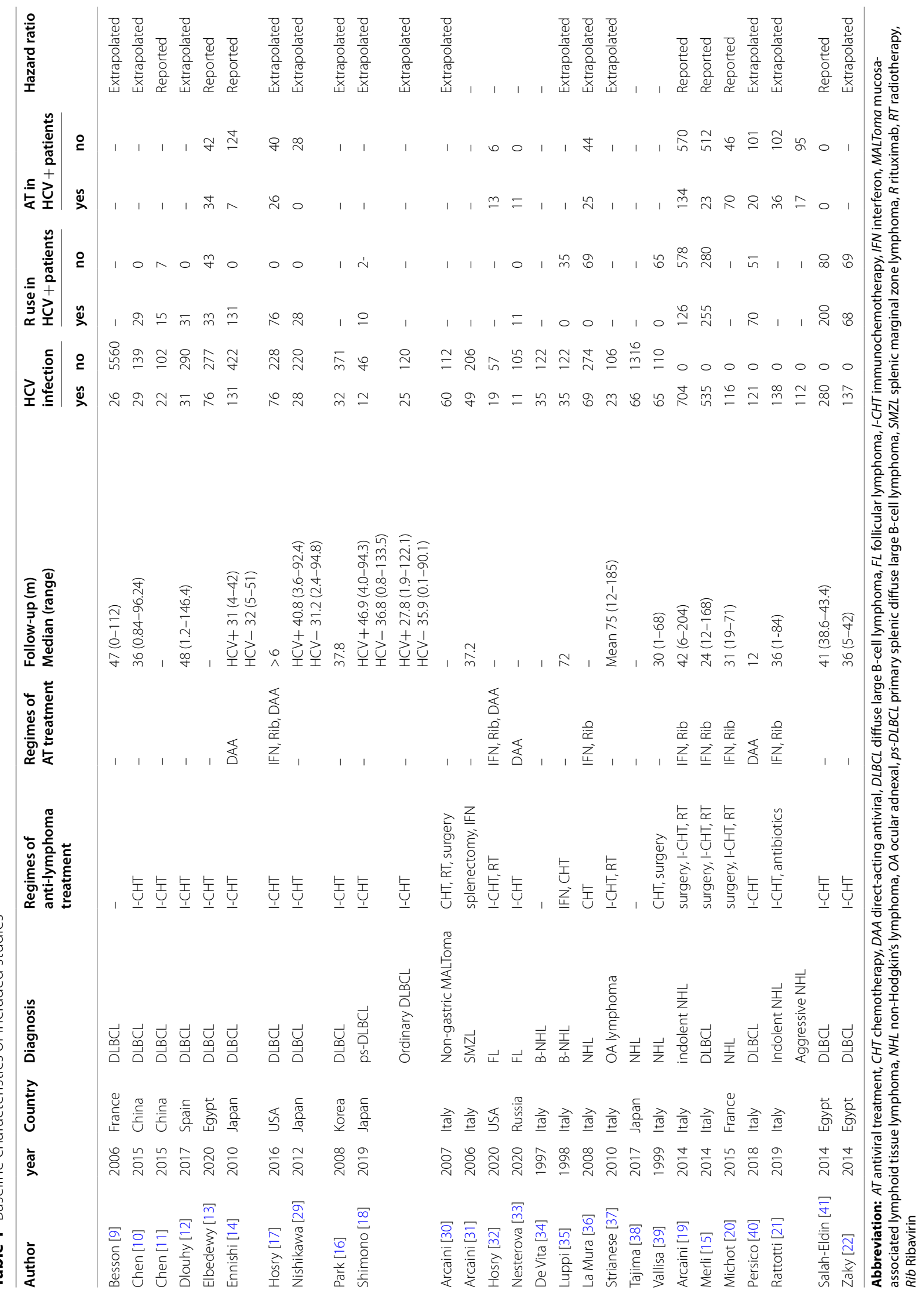




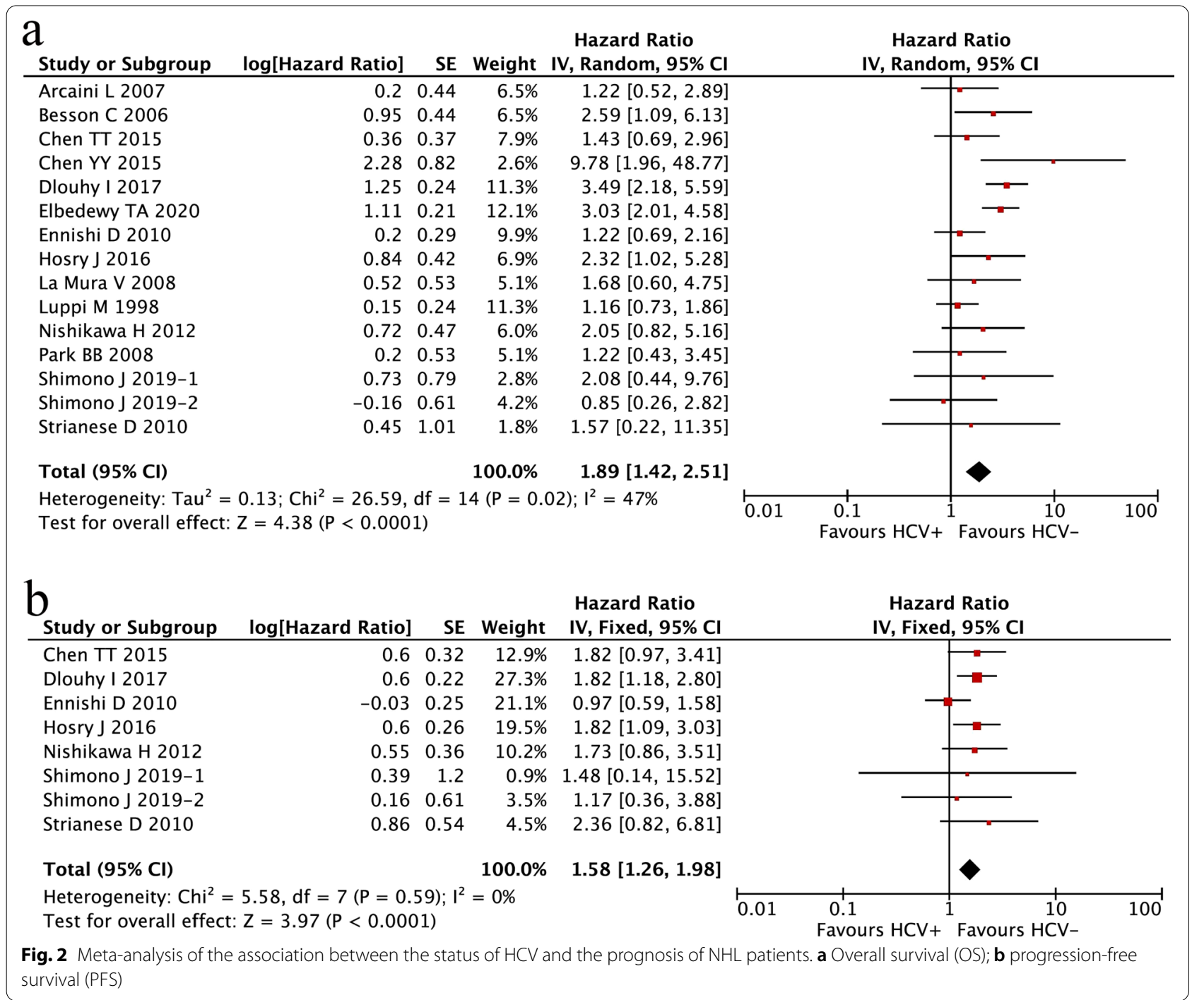

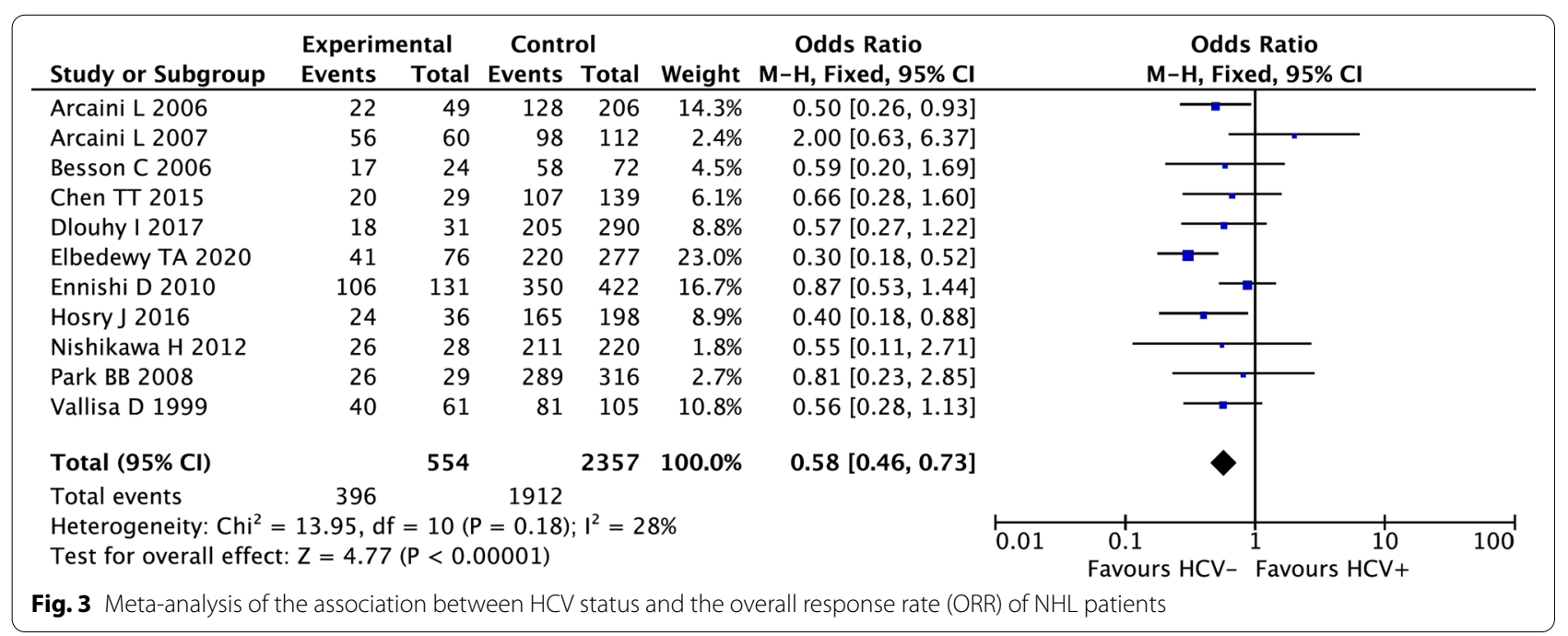




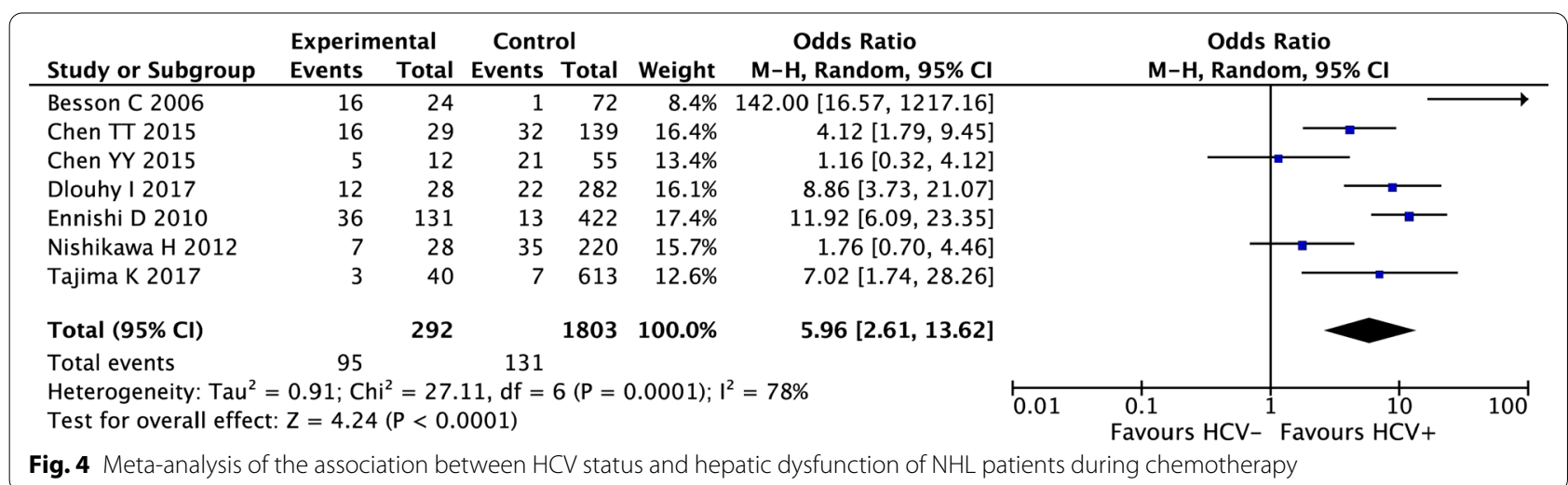

\section{$\mathrm{HCV}$ infection and clinical characteristics}

The clinical features of NHL patients were also comprehensively compared between HCV-positive and HCVnegative NHL patients. The results indicated that $\mathrm{HCV}$ infection was associated with an advanced disease stage (OR 1.42, 95\% CI 1.14-1.76, $\mathrm{P}=0.001$, Additional file 3: Figure S1), an elevated level of LDH (OR 1.44; 95\% CI 1.17-1.79, $\mathrm{P}=0.0008$, Additional file 4: Figure S2), a high-intermediate and high IPI/FLIPI risk (OR 1.29; 95\% CI 1.07-1.56, $\mathrm{P}=0.008$, Additional file 5: Figure S3), as well as a higher incidence of spleen involvement (OR 2.95; 95\% CI 2.17-4.02, $\mathrm{P}<0.00001$, Additional file 6: Figure S4) and liver involvement (OR 2.01; 95\% CI 1.462.78, $\mathrm{P}<0.0001$, Additional file 7: Figure S5). However, there was no significant difference in the age of disease onset (Additional file 8: Figure S6), presence of B symptoms (Additional file 9: Figure S7) or the incidence of the involvement of bone marrow (Additional file 10: Figure S8) between the two groups of patients.

\section{Effect of antiviral treatment and rituximab administration on HCV-associated NHL patients}

Since NHL patients with HCV infection were found to have disadvantages of survival and treatment responses, whether antiviral treatment may improve the clinical outcomes of $\mathrm{HCV}$-associated NHL patients was also investigated. Among all of the studies reviewed, 9 studies including $1838 \mathrm{HCV}$-infected NHL patients were included to evaluate the impact of antiviral treatment on OS, PFS/DFS and ORR. As shown in Fig. 5, antiviral treatment was associated with an improved OS (HR 0.38; 95\% CI 0.24-0.60, P < 0.0001; Fig. 5a) and PFS/DFS (HR 0.63; 95\% CI 0.46-0.86, $\mathrm{P}=0.003$; Fig. 5b), as well as a higher ORR (OR 2.62; 95\% CI 1.34-5.11, $\mathrm{P}=0.005$, Fig. 5c) in comparison with patients without antiviral treatment.
In addition, we also explored whether rituximab-containing regimens could improve the clinical prognosis of HCV-positive NHL patients. Four studies comprising 688 participants (DLBCL patients) were evaluated. The results demonstrated that patients treated with rituximab-containing chemotherapy exhibited favourable OS compared with those receiving rituximab-free chemotherapy (HR 0.68; 95\% CI 0.54-0.86, P=0.001; Fig. 6a). However, no difference in PFS was observed between these two groups of patients (HR 0.97; 95\% CI 0.70-1.36, $\mathrm{P}=0.88$; Fig. 6b).

\section{Liver-related survival factors in HCV-associated NHL patients}

We subsequently evaluated liver-related survival factors in HCV-associated NHL patients, including liver cirrhosis, liver involvement, low levels of albumin $(<3.5 \mathrm{~g} / \mathrm{dl})$ and elevated alanine transaminase (ALT). As shown in Fig. 7a-d, low levels of albumin (HR 2.61; 95\% CI 1.713.97, $\mathrm{P}<0.00001$; Fig. 7a) and liver cirrhosis (HR 2.91; 95\% CI 1.44-5.88, P =0.003; Fig. 7b) were significantly associated with an inferior OS. There was a trend for an association between liver involvement and a short OS (HR 1.27; 95\% CI 0.96-1.67, P=0.09; Fig. 7c). However, no association was found between elevated ALT and OS (HR 1.09; 95\% CI 0.86-1.37, P=0.50; Fig. 7d).

\section{Subgroup analysis}

Subgroup analysis was conducted based on the prevalence of HCV infection. According to the 2017 report of the prevalence of $\mathrm{HCV}$ infection from the WHO [42], the countries among the included studies were divided into high prevalence of $\mathrm{HCV}$ infection, including Italy, Spain, France, Russia and Egypt, and low prevalence of $\mathrm{HCV}$ infection, including the United States, Japan, Korea, and China (using a cut-off value of HCV infection prevalence at $1.5 \%)$. The results of the subgroup analysis 


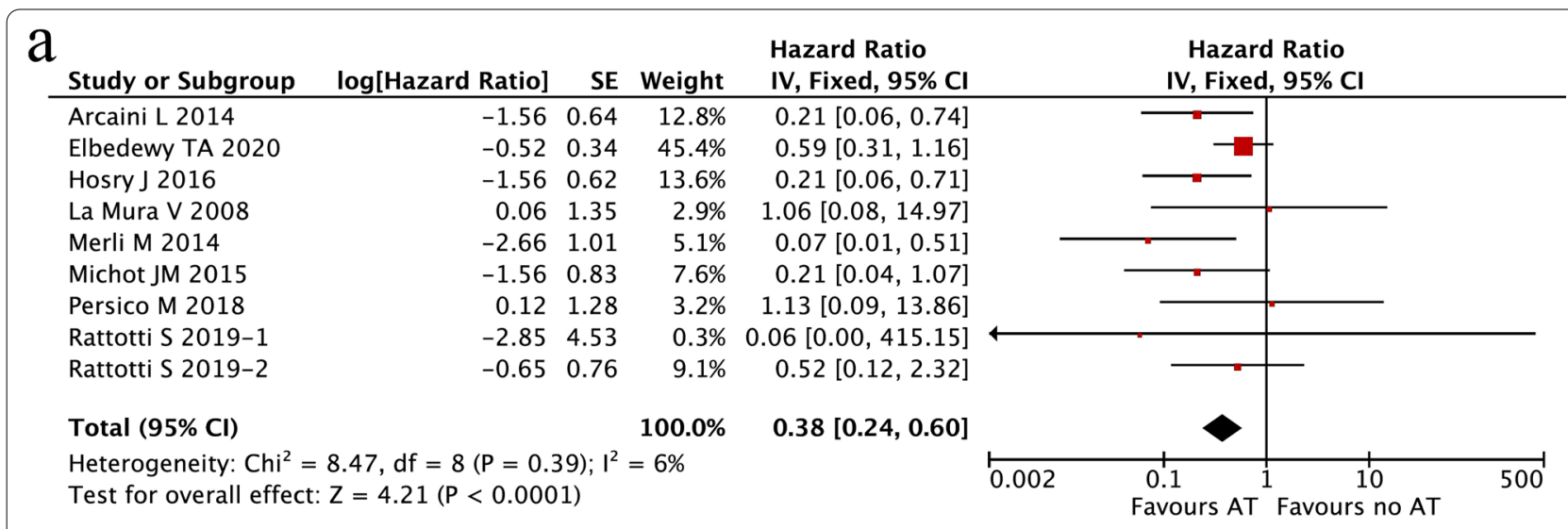

b

\begin{tabular}{|c|c|c|c|c|c|c|c|c|c|}
\hline Study or Subgroup & log[Hazard Ratio] & SE & Weight & $\begin{array}{l}\text { Hazard Ratio } \\
\text { IV, Fixed, 95\% CI }\end{array}$ & & $\begin{array}{l}\text { Hazar } \\
\text { IV, Fixec }\end{array}$ & $\begin{array}{l}\text { d Ratio } \\
\text {, } 95 \% \mathrm{Cl}\end{array}$ & & \\
\hline Arcaini L 2014 & -0.22 & 0.26 & $37.0 \%$ & $0.80[0.48,1.34]$ & & $\rightarrow$ & 3 & & \\
\hline Hosry J 2016 & 0.01 & 0.42 & $14.2 \%$ & $1.01[0.44,2.30]$ & & & & & \\
\hline La Mura V 2008 & -1.24 & 0.52 & $9.3 \%$ & $0.29[0.10,0.80]$ & & & & & \\
\hline Merli M 2014 & -0.36 & 0.32 & $24.5 \%$ & $0.70[0.37,1.31]$ & & & & & \\
\hline Michot JM 2015 & -1.14 & 0.64 & $6.1 \%$ & $0.32[0.09,1.12]$ & & & & & \\
\hline Persico M 2018 & -1.28 & 0.53 & $8.9 \%$ & $0.28[0.10,0.79]$ & & & & & \\
\hline Total $(95 \% \mathrm{Cl})$ & & & $100.0 \%$ & $0.63[0.46,0.86]$ & & & & & \\
\hline \multicolumn{4}{|c|}{$\begin{array}{l}\text { Heterogeneity: } \mathrm{Chi}^{2}=7.97, \mathrm{df}=5(\mathrm{P}=0.16) ; \mathrm{I}^{2}=37 \% \\
\text { Test for overall effect: } Z=2.95(P=0.003)\end{array}$} & & 0.01 & 0.1 Favours AT & 1 Favours & $\begin{array}{c}10 \\
\text { no AT }\end{array}$ & 100 \\
\hline
\end{tabular}

\begin{tabular}{|c|c|c|c|c|c|c|c|c|c|c|}
\hline Study or Subgroup & \multicolumn{2}{|c|}{ Experimental } & $\begin{array}{c}\text { Contr } \\
\text { Events }\end{array}$ & $\begin{array}{l}\text { ol } \\
\text { Total }\end{array}$ & Weight & $\begin{array}{c}\text { Odds Ratio } \\
\text { M-H, Fixed, 95\% Cl }\end{array}$ & \multicolumn{4}{|c|}{$\begin{array}{c}\text { Odds Ratio } \\
\text { M-H, Fixed, 95\% Cl }\end{array}$} \\
\hline Elbedewy TA 2020 & 24 & 34 & 17 & 42 & $38.8 \%$ & $3.53[1.35,9.23]$ & & & 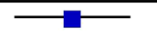 & \\
\hline Hosry J 2016 & 22 & 26 & 24 & 36 & $26.8 \%$ & $2.75[0.77,9.80]$ & & & & \\
\hline Persico M 2018 & 17 & 20 & 80 & 101 & $34.4 \%$ & $1.49[0.40,5.56]$ & & & & \\
\hline Total $(95 \% \mathrm{Cl})$ & & 80 & & 179 & $100.0 \%$ & $2.62[1.34,5.11]$ & & & & \\
\hline Total events & 63 & & 121 & & & & & & & \\
\hline $\begin{array}{l}\text { Heterogeneity: } \mathrm{Chi}^{2}= \\
\text { Test for overall effect }\end{array}$ & $\begin{array}{l}1.08, \mathrm{df}= \\
Z=2.82\end{array}$ & $\begin{array}{l}2(P= \\
(P=0 .\end{array}$ & $\begin{array}{l}0.58) ; 1^{2} \\
05)\end{array}$ & $=0 \%$ & & & 0.01 & $\begin{array}{c}0.1 \\
\text { Favours no AT }\end{array}$ & Favours AT & 100 \\
\hline
\end{tabular}

Fig. 5 Meta-analysis of the clinical outcomes between HCV-associated NHL patients receiving antiviral treatment and those not receiving antiviral treatment. a Overall survival (OS); b progression-free survival/disease-free survival (PFS/DFS); c overall response rate (ORR)

are shown in Table 2 (high prevalence) and Table 3 (low prevalence). Compared with the results from the overall population, similar results could be observed in the subgroup analysis. NHL patients with HCV infection had an inferior prognosis, a reduced treatment response and a higher incidence of hepatic dysfunction in both subpopulations. With regard to clinical features, HCV infection had no effect on the IPI/FLIPI risk in either subgroup of patients, which was inconsistent with this outcome in the overall population. In addition, $\mathrm{HCV}$-associated NHL patients had an early age of disease onset among the countries with a low prevalence of $\mathrm{HCV}$ infection. For the outcomes of the effect of antiviral and rituximab treatment as well as survival factors in $\mathrm{HCV}$-positive
NHL patients, all of the included studies were performed in countries with a high prevalence of HCV infection, except one study [17]. Therefore, subgroup analysis was not performed.

Since NHL is a group of heterogeneous diseases, we performed subgroup analysis based on the pathological types of NHL. In the current study, the majority of the included studies focused on DLBCL; hence, subgroup analysis was conducted in DLBCL patients. Similar to the overall patients, DLBCL patients with $\mathrm{HCV}$ infection had shorter OS and PFS, lower ORR and distinct clinical features in comparison to DLBCL patients without $\mathrm{HCV}$ infection. Moreover, $\mathrm{HCV}$-associated DLBCL patients receiving antiviral treatment shared a better OS and PFS/ 


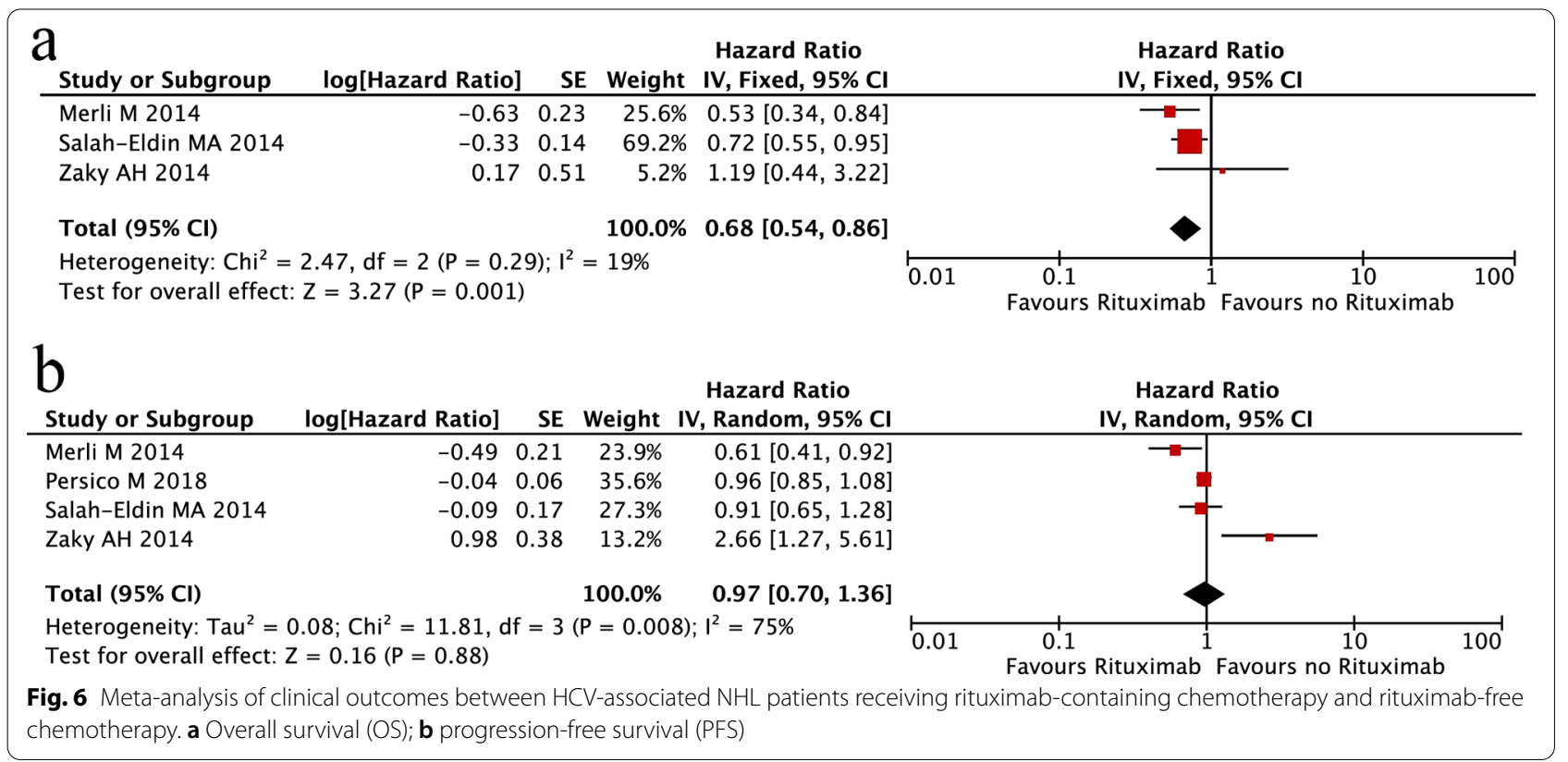

DFS than patients without antiviral treatment. Due to the small sample size, subgroup analysis was not performed in terms of the outcomes of liver-related survival factors. The results of the subgroup analysis of DLBCL patients are summarized in Table 4.

In terms of antiviral treatment, subgroup analysis was performed based on the regimens of antiviral treatment. Among the 9 included studies, the patients in most studies $(n=6)$ received interferon (IFN) \pm ribavirin as antiviral treatment. Only two studies $[13,40]$ focused on new direct-acting antiviral (DAA) treatments of $\mathrm{HCV}$, and another study [17] consisted of different types of antiviral treatment. Therefore, subgroup analysis was conducted in patients receiving $I F N \pm$ ribavirin. The results suggested that patients receiving IFN \pm ribavirin had obviously improved OS (HR 0.25; 95\% CI 0.12-0.52, $\mathrm{P}=0.0002$, figure not shown) and PFS (HR 0.63; 95\% CI $0.44-0.90, \mathrm{P}=0.01$, figure not shown) compared with patients without antiviral treatment.

\section{Sensitivity analysis}

Sensitivity analysis was performed by sequentially excluding individual studies to determine the origin of the heterogeneity and to verify the sensitivity of the results. The origin of the heterogeneity and overall effect after removal of the origin of the heterogeneity for each outcome are summarized in Table 5. The results showed that removal of the origin of the heterogeneity did not affect the effect size for each outcome, suggesting the stability of the results of the meta-analysis. However, for the outcomes of age of disease onset and hepatic dysfunction during chemotherapy, heterogeneity still existed even though the studies were excluded one by one.

\section{Publication bias}

Begg's test and Egger's test were performed to assess publication bias. As shown in Table 6, no significant publication bias was observed for any of the outcomes.

\section{Discussion}

Over the past two decades, considerable studies have investigated the contribution of $\mathrm{HCV}$ infection to lymphomagenesis. However, the mechanisms of $\mathrm{HCV}$ associated lymphoma remain elusive. Experimental data showed that HCV-induced lymphoma development may act through multistep processes involving a variety of oncogenic mechanisms, such as HCV-induced chronic B-cell immune stimulation, genetic damage, and dysregulation of signalling pathways (NF-kB, JNF, ERK and NOTCH signalling pathways) [43-48]. A prognostic evaluation of clinical outcomes and therapeutic responses in $\mathrm{HCV}$-associated lymphoma is essential to antitumour treatment. Herein, we performed a systematic review and meta-analysis to assess the impact of $\mathrm{HCV}$ infection on NHL patients. Furthermore, subgroup analysis was also performed based on the prevalence of $\mathrm{HCV}$ infection and the pathological types of lymphoma. The results of the current study collectively indicated that HCV-positive NHL patients had significantly inferior survivals, earlier disease progression, worse treatment responses and distinct clinical characteristics. In addition to the recognized survival factors of NHL, our study 


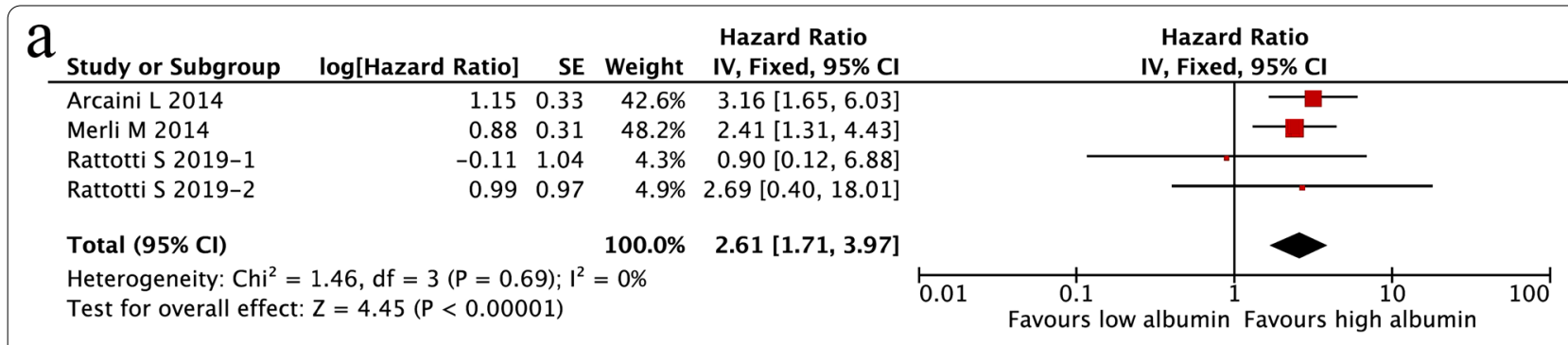

b

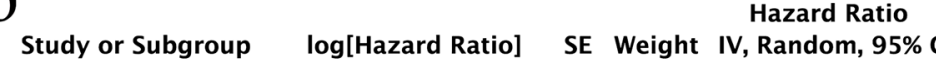

\begin{tabular}{lllll}
\hline Arcaini L 2014 & 1.03 & 0.42 & $21.0 \%$ & 2.80 \\
{$[1.23,6.38]$}
\end{tabular}

$\begin{array}{lllll}\text { Hosry J } 2016 & 2.45 & 0.55 & 17.4 \% & 11.59[3.94,34.06]\end{array}$

$\begin{array}{lllll}\text { Michot JM } 2015 & 1.14 & 0.68 & 14.3 \% & 3.13[0.82,11.86]\end{array}$

Rattotti S 2019-1

$\begin{array}{rrrr}0.26 & 0.74 & 13.1 \% & 1.30[0.30,5.53]\end{array}$

Rattotti S 2019-2

$\begin{array}{llll}1.57 & 1.04 & 8.5 \% & 4.81[0.63,36.91]\end{array}$

Salah-Eldin MA 2014

$\begin{array}{llll}0.37 & 0.25 & 25.7 \% & 1.45[0.89,2.36]\end{array}$

Total $(95 \% \mathrm{Cl})$

$100.0 \% \quad 2.91[1.44,5.88]$

Heterogeneity: $\mathrm{Tau}^{2}=0.44 ; \mathrm{Chi}^{2}=13.59, \mathrm{df}=5(\mathrm{P}=0.02) ; \mathrm{I}^{2}=63 \%$

Test for overall effect: $Z=2.97(P=0.003)$

C

$\begin{array}{llll}\text { Study or Subgroup } & \text { log[Hazard Ratio] } & \text { SE Weight } & \begin{array}{c}\text { Hazard Ratio } \\ \text { IV, Fixed, 95\% CI }\end{array}\end{array}$

\begin{tabular}{llllll}
\hline Arcaini L 2014 & 0.1 & 0.31 & $20.6 \%$ & $1.11[0.60,2.03]$
\end{tabular}

Merli M $2014 \quad 0.42 \quad 0.21 \quad 45.0 \% \quad 1.52[1.01,2.30]$

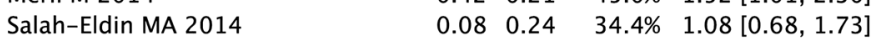

Total $(95 \% \mathrm{Cl})$

$100.0 \% 1.27[0.96,1.67]$

Heterogeneity: $\mathrm{Chi}^{2}=1.38, \mathrm{df}=2(\mathrm{P}=0.50) ; \mathrm{I}^{2}=0 \%$

Test for overall effect: $Z=1.68(P=0.09)$

Hazard Ratio

IV, Random, $95 \% \mathrm{CI}$

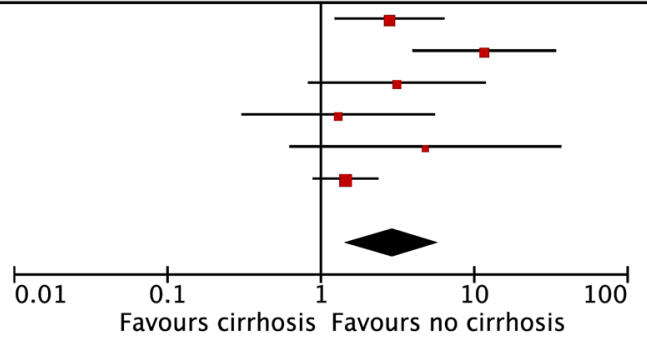

d

\begin{tabular}{llll} 
Study or Subgroup & log[Hazard Ratio] & SE Weight & Hazard Ratio \\
\hline & & Fixed, 95\% CI
\end{tabular}

\begin{tabular}{lrrrr}
\hline Arcaini L 2014 & 0 & 0.18 & $44.7 \%$ & 1.00 \\
{$[0.70,1.42]$}
\end{tabular}

Merli M $2014 \quad 0.04 \quad 0.18 \quad 44.7 \% \quad 1.04[0.73,1.48]$

Rattotti S 2019-1

$\begin{array}{llll}0.59 & 0.49 & 6.0 \% & 1.80[0.69,4.71]\end{array}$

Rattotti S 2019-2

$\begin{array}{llll}0.64 & 0.57 & 4.5 \% & 1.90[0.62,5.80]\end{array}$

Total $(95 \% \mathrm{CI})$

$100.0 \% \quad 1.09[0.86,1.37]$

Heterogeneity: $\mathrm{Chi}^{2}=2.30, \mathrm{df}=3(\mathrm{P}=0.51) ; \mathrm{I}^{2}=0 \%$

Test for overall effect: $Z=0.68(P=0.50)$

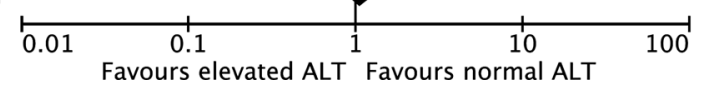

Fig. 7 Meta-analysis of prognostic factors among HCV-associated NHL patients. a Liver cirrhosis; b low level of albumin; c liver involvement; $\mathbf{d}$ elevated alanine transaminase (ALT)

also demonstrated that liver cirrhosis and low levels of albumin were inferior prognostic factors of OS for HCVassociated NHL patients.

Furthermore, this study implicated the anti-lymphoma efficacy of antiviral treatment, especially IFN \pm ribavirin regimens, in $\mathrm{HCV}$-associated NHL patients, which was similar to the findings of a recent meta-analysis conducted by Peveling-Oberhag et al. [49]. The authors found a good overall lymphoma response rate through the application of antiviral treatment in $\mathrm{HCV}$-infected NHL patients. However, their meta-analysis was based on small studies, mostly case reports or small cohorts with fewer than 20 cases. Nevertheless, DAA treatments are radically changing the landscape of anti-HCV therapy. In the current study, whether HCV-associated NHL patients can benefit from DAA treatment could not be expounded upon due to the small patient sample size. In the era of DAA, future studies should investigate the anti-lymphoma activity of DAA treatment in NHL patients with $\mathrm{HCV}$ infection.

On the other hand, rituximab-containing regimens have been proven to be associated with better treatment responses and clinical prognosis in DLBCL over the past two decades. In the current study, we also found that 
Table 2 Subgroup analysis in countries with high prevalence of HCV infection

\begin{tabular}{|c|c|c|c|c|c|}
\hline \multirow[t]{2}{*}{ Outcome } & \multirow[t]{2}{*}{ Studies } & \multirow[t]{2}{*}{ HR/OR (95\%Cl) } & \multirow[t]{2}{*}{ P value } & \multicolumn{2}{|c|}{ Heterogeneity } \\
\hline & & & & $I^{2} \%$ & P value \\
\hline \multicolumn{6}{|l|}{ Impact of HCV infection } \\
\hline Overall survival & 7 & $2.07(1.37-3.14)$ & 0.0006 & 61 & 0.02 \\
\hline Progression-free survival & 2 & $1.89(1.27-2.82)$ & 0.002 & 0 & 0.66 \\
\hline Overall response rate & 6 & $0.51(0.38-0.68)$ & $<0.00001$ & 46 & 0.10 \\
\hline Hepatic dysfunction & 2 & $30.13(1.75-517.77)$ & 0.02 & 84 & 0.01 \\
\hline Age of onset & 5 & $1.04(0.50-2.16)$ & 0.92 & 79 & 0.0009 \\
\hline Advanced disease stage & 11 & $1.53(1.22-1.91)$ & 0.0002 & 44 & 0.06 \\
\hline Presence of B symptom & 6 & $0.99(0.53-1.84)$ & 0.97 & 63 & 0.02 \\
\hline Elevated LDH level & 5 & $1.33(0.96-1.84)$ & 0.09 & 49 & 0.10 \\
\hline $\mathrm{H}-\mathrm{l} / \mathrm{H}$ risk & 6 & $1.53(0.96-2.44)$ & 0.07 & 60 & 0.03 \\
\hline Spleen involvement & 4 & $3.74(2.32-6.02)$ & $<0.00001$ & 0 & 0.52 \\
\hline Liver involvement & 5 & $1.98(1.23-3.20)$ & 0.005 & 41 & 0.15 \\
\hline Bone marrow involvement & 6 & $1.39(0.97-2.00)$ & 0.07 & 46 & 0.10 \\
\hline
\end{tabular}

Abbreviation: $\mathrm{H}-\mathrm{I} / \mathrm{H}$ high-intermediate and high

Table 3 Subgroup analysis in countries with low prevalence of HCV infection

\begin{tabular}{|c|c|c|c|c|c|}
\hline \multirow[t]{2}{*}{ Outcome } & \multirow[t]{2}{*}{ Studies } & \multirow[t]{2}{*}{ HR/OR (95\%Cl) } & \multirow[t]{2}{*}{ P value } & \multicolumn{2}{|c|}{ Heterogeneity } \\
\hline & & & & $\mathrm{I}^{2} \%$ & $P$ value \\
\hline \multicolumn{6}{|l|}{ Impact of HCV infection } \\
\hline Overall survival & 8 & $1.59(1.16-2.17)$ & 0.004 & 16 & 0.31 \\
\hline Progression-free survival & 6 & $1.45(1.10-1.90)$ & 0.008 & 0 & 0.52 \\
\hline Overall response rate & 5 & $0.70(0.49-1.00)$ & 0.05 & 0 & 0.59 \\
\hline Hepatic dysfunction & 5 & $3.87(1.60-9.36)$ & 0.003 & 76 & 0.002 \\
\hline Age of onset & 4 & $1.97(1.18-3.28)$ & 0.01 & 4 & 0.37 \\
\hline Advanced disease stage & 10 & $1.22(0.98-1.52)$ & 0.07 & 28 & 0.18 \\
\hline Presence of B symptom & 4 & $0.80(0.53-1.21)$ & 0.30 & 47 & 0.13 \\
\hline Elevated LDH level & 6 & $1.54(1.16-2.04)$ & 0.003 & 26 & 0.24 \\
\hline $\mathrm{H}-\mathrm{l} / \mathrm{H}$ risk & 8 & $1.16(0.89-1.51)$ & 0.26 & 0 & 0.52 \\
\hline Spleen involvement & 5 & $2.48(1.65-3.74)$ & $<0.0001$ & 0 & 0.63 \\
\hline Liver involvement & 7 & $2.04(1.32-3.15)$ & 0.001 & 17 & 0.30 \\
\hline Bone marrow involvement & 8 & $0.98(0.72-1.34)$ & 0.90 & 0 & 0.46 \\
\hline
\end{tabular}

Abbreviation: $\mathrm{H}-\mathrm{I} / \mathrm{H}$ high-intermediate and high

rituximab administration could improve OS in DLBCL patients with HCV infection. However, the association between PFS and rituximab administration could not be observed in this specific subtype of DLBCL patients, which might be due to the small sample size. Whether rituximab-containing regimens can improve the treatment response and PFS warrants further study with larger cohorts.

To the best of our knowledge, this is the first metaanalysis that systematically assessed the clinical outcomes and treatment of $\mathrm{HCV}$-associated NHL patients. We are confident that our results are reliable, since they were supported by a large sample size, moderate to high methodological quality of the included studies, low heterogeneity, and no publication bias. However, there were several limitations of this study. First, when evaluating OS or PFS/DFS, HRs and 95\% CIs in some individual studies were not available from the original articles; hence, they were indirectly calculated from Kaplan-Meier curves. Second, our study found that a higher incidence of hepatic dysfunction was observed in HCV-infected NHL patients, probably leading to delays or termination of chemotherapy or even death. However, the direct cause-and-effect relationship between hepatic dysfunction and the inferior prognosis remains unknown. On the other hand, it is still unclear whether the survival benefit 
Table 4 Subgroup analysis in DLBCL patients

\begin{tabular}{|c|c|c|c|c|c|}
\hline \multirow[t]{2}{*}{ Outcome } & \multirow[t]{2}{*}{ Studies } & \multirow[t]{2}{*}{ HR/OR $(95 \% C l)$} & \multirow[t]{2}{*}{ P value } & \multicolumn{2}{|c|}{ Heterogeneity } \\
\hline & & & & $I^{2} \%$ & P value \\
\hline \multicolumn{6}{|l|}{ Impact of HCV infection } \\
\hline Overall survival & 11 & $2.29(1.85-2.84)$ & $<0.00001$ & 46 & 0.05 \\
\hline Progression-free survival & 7 & $1.55(1.23-1.95)$ & 0.0002 & 0 & 0.54 \\
\hline Overall response rate & 8 & $0.55(0.42-0.72)$ & $<0.00001$ & 23 & 0.24 \\
\hline Hepatic dysfunction & 6 & $5.89(2.31-15.01)$ & 0.0002 & 82 & $<0.0001$ \\
\hline Age of onset & 7 & $1.31(0.67-2.57)$ & 0.43 & 70 & 0.003 \\
\hline Advanced disease stage & 11 & $1.20(0.98-1.48)$ & 0.08 & 14 & 0.31 \\
\hline Presence of B symptom & 6 & $1.16(0.70-1.94)$ & 0.56 & 59 & 0.03 \\
\hline Elevated LDH level & 9 & $1.47(1.17-1.85)$ & 0.0009 & 46 & 0.06 \\
\hline $\mathrm{H}-\mathrm{l} / \mathrm{H}$ risk & 10 & $1.34(1.07-1.67)$ & 0.01 & 0 & 0.48 \\
\hline Spleen involvement & 5 & $2.75(1.92-3.95)$ & $<0.00001$ & 0 & 0.55 \\
\hline Liver involvement & 7 & $1.87(1.22-2.85)$ & 0.004 & 0 & 0.60 \\
\hline Bone marrow involvement & 6 & $1.03(0.71-1.50)$ & 0.86 & 17 & 0.31 \\
\hline \multicolumn{6}{|l|}{ Impact of anti-viral treatment } \\
\hline Overall survival & 5 & $0.40(0.24-0.66)$ & 0.0003 & 37 & 0.18 \\
\hline $\begin{array}{l}\text { Progression-free survival/disease-free } \\
\text { survival }\end{array}$ & 4 & $0.60(0.39-0.92)$ & 0.02 & 41 & 0.17 \\
\hline
\end{tabular}

Abbreviation: $\mathrm{H}-\mathrm{I} / \mathrm{H}$ high-intermediate and high

Table 5 Results of sensitivity analysis

\begin{tabular}{llll}
\hline Outcome & Origin of heterogeneity & Overall effect & P value \\
\hline Overall survival & Dlouhy I 2017 [12] & $1.78(1.45-2.18)$ & $<0.00001$ \\
Advanced disease stage & Vallisa D 1999 [39] & $1.28(1.09-1.51)$ & 0.003 \\
Presence of B symptoms & Arcaini L 2006 [31] & $1.09(0.84-1.41)$ & 0.51 \\
Liver cirrhosis & Hosry J 2016 [17] & $1.84(1.26-2.69)$ & 0.002 \\
\hline
\end{tabular}

of antiviral treatment is attributed to restoring hepatic dysfunction and reducing the chance of termination or delay of chemotherapy caused by HCV-induced hepatotoxicity. Third, our study found that HCV infection was associated with poor survival in NHL patients. However, when we attempted to further perform prognostic evaluation of HCV viral loading (HCV-RNA) in HCV-infected NHL patients, we found that only two articles investigated the prognostic value of HCV-RNA, and the results were contradictory. Fourth, it should be noted that when analysing some outcomes, such as prognostic factors and the effect of rituximab administration to $\mathrm{HCV}$ associated NHL patients, only a few studies with small sample sizes could be included. Therefore, the results of these outcomes need to be interpreted with caution. Fifth, although we performed comprehensive literature search, most of the included studies were retrospective studies. Therefore, HCV-negative NHL patients in our study might not fully represent the whole $\mathrm{HCV}$-negative
NHL population. Last, patients in most of the included studies had DLBCL. There were only a few studies focusing on indolent lymphoma, such as follicular lymphoma and marginal zone lymphoma; hence, subgroup analysis could not be carried out for indolent lymphoma patients. In view of the limitations of the current study, welldesigned prospective studies with large cohorts should be further performed in the different subtypes of NHL, especially indolent lymphoma, to address the issues mentioned above.

\section{Conclusions}

This meta-analysis confirmed the inferior prognosis and distinct clinical characteristics of $\mathrm{HCV}$-associated NHL patients, especially in DLBCL. Patients with HCV infection were prone to undergoing hepatic dysfunction during chemotherapy. Moreover, our data provide compelling evidence that antiviral treatment combined 
Table 6 Results of Begg's test and Egger's test

\begin{tabular}{lll}
\hline Outcome & $\mathbf{P}_{\text {Begg's test }}$ & $\mathbf{P}_{\text {Egger's test }}$ \\
\hline Impact of HCV infection & & \\
Overall survival & 1.000 & 0.619 \\
Progression-free survival & 0.386 & 0.871 \\
Overall response rate & 0.276 & 0.373 \\
Hepatic dysfunction & 0.452 & 0.236 \\
Age of onset & 1.000 & 0.499 \\
Advanced disease stage & 0.162 & 0.468 \\
Presence of B symptom & 0.074 & 0.065 \\
Elevated LDH level & 0.533 & 0.639 \\
H-I/H risk & 0.125 & 0.379 \\
Spleen involvement & 0.386 & 0.878 \\
Liver involvement & 1.000 & 0.895 \\
Bone marrow involvement & 0.100 & 0.167 \\
Impact of antiviral treatment & & \\
Overall survival & 0.917 & 0.407 \\
Progression-free survival/disease- & 0.260 & 0.070 \\
free survival & & \\
Liver-related survival factors & & 0.262 \\
Liver cirrhosis & 0.707 & \\
\hline
\end{tabular}

Abbreviation: $H-I / H$ high-intermediate and high

with immunochemotherapy may represent an effective approach for HCV-positive NHL patients.

\section{Abbreviations}

ALT: Alanine transaminase; Cl: Confidence interval; DAA: Direct-acting antiviral; DFS: Disease-free survival; DLBCL: Diffuse large B-cell lymphoma; HCV: Hepatitis C virus; HR: Hazard ratio; IFN: Interferon; NHL: Non-Hodgkin's lymphoma; NOS: Newcastle-Ottawa Quality Assessment Scale; PFS: Progression-free survival; OR: Odds ratio; ORR: Overall response rate; OS: Overall survival; WHO: World Health Organization.

\section{Supplementary Information}

The online version contains supplementary material available at https://doi. org/10.1186/s12935-021-02230-1.

Additional file 1: Table S1. Literature search strategy in different electronic databases.

Additional file 2: Table S2. Quality assessment results of included studies.

Additional file 3: Figure S1. Meta-analysis of the association between HCV status and advanced disease stage (Ann Arbor staging III/IV) in NHL patients.

Additional file 4: Figure S2. Meta-analysis of the association between HCV status and elevated LDH levels in NHL patients.

Additional file 5: Figure S3. Meta-analysis of the association between $\mathrm{HCV}$ status and the intermediate-high and high IPI/FLIPI risk in NHL patients.

Additional file 6: Figure S4. Meta-analysis of the association between HCV status and spleen involvement in NHL patients.

Additional file 7: Figure S5. Meta-analysis of the association between HCV status and liver involvement in NHL patients.
Additional file 8: Figure S6. Meta-analysis of the association between HCV status and the age of disease onset in NHL patients.

Additional file 9: Figure S7. Meta-analysis of the association between $\mathrm{HCV}$ status and the presence of B symptoms in NHL patients.

Additional file 10: Figure S8. Meta-analysis of the association between HCV status and bone marrow involvement in NHL patients.

\section{Acknowledgements}

We would like to thank Dr. Lok Hay Yim for her guidance on this article and for her editing and proofreading of this English manuscript.

\section{Authors' contributions}

$B N$ and $P Z$ performed literature research. MZ, FG and LP extracted and analyzed the data. MZ, FG and LS wrote the manuscript; $\mathrm{HH}$ and JH conceived and designed this study. All authors reviewed the final manuscript. All authors read and approved the final manuscript.

\section{Funding}

This work was supported by Science and Technology Development Foundation of Shanghai Pudong New Area health and Family Planning Commission (PW2015E-1) and National Natural Science Foundation of China (81903811).

\section{Availability of data and materials}

The datasets used in this study are available from the corresponding author upon reasonable request.

\section{Declarations}

Ethics approval and consent to participate

Not applicable.

\section{Consent for publication \\ Not applicable.}

\section{Competing interests}

The authors declare that they have no competing interests.

\section{Author details}

'Division of Hematology, Renji Hospital, School of Medicine, Shanghai Jiaotong University, Shanghai 200127, China. ${ }^{2}$ State Key Laboratory of Southwestern Chinese Medicine Resources, Pharmacy School, Chengdu University of Traditional Chinese Medicine, Chengdu 611730, China. ${ }^{3}$ Division of Chinese Medicine, M.D. Prefectural People's Hospital, Chuxiong Yi Autonomous Prefecture 675500, China.

Received: 12 May 2021 Accepted: 27 September 2021

Published online: 09 October 2021

\section{References}

1. de The G. Viruses and human cancers: challenges for preventive strategies. Environ Health Perspect. 1995;103(Suppl 8):269-73.

2. Parsonnet J, Isaacson PG. Bacterial infection and MALT lymphoma. N Engl J Med. 2004;350(3):213-5.

3. Raderer M, Kiesewetter B, Ferreri AJ. Clinicopathologic characteristics and treatment of marginal zone lymphoma of mucosa-associated lymphoid tissue (MALT lymphoma). CA Cancer J Clin. 2016;66(2):153-71.

4. Swerdlow SH, Campo E, Pileri SA, Harris NL, Stein H, Siebert R, et al. The 2016 revision of the World Health Organization classification of lymphoid neoplasms. Blood. 2016;127(20):2375-90.

5. Pal S, Sullivan DG, Kim S, Lai KK, Kae J, Cotler SJ, et al. Productive replication of hepatitis $\mathrm{C}$ virus in perihepatic lymph nodes in vivo: implications of HCV lymphotropism. Gastroenterology. 2006;130(4):1107-16.

6. Pham TN, King D, Macparland SA, McGrath JS, Reddy SB, Bursey FR, et al. Hepatitis $C$ virus replicates in the same immune cell subsets in chronic hepatitis $C$ and occult infection. Gastroenterology. 2008;134(3):812-22. 
7. Canioni D, Michot JM, Rabiega P, Molina TJ, Charlotte F, Lazure T, et al. In situ hepatitis C NS3 protein detection is associated with high grade features in hepatitis C-associated B-cell non-Hodgkin lymphomas. PLoS ONE. 2016;11(6)::0156384.

8. Dal Maso L, Franceschi S. Hepatitis C virus and risk of lymphoma and other lymphoid neoplasms: a meta-analysis of epidemiologic studies. Cancer Epidemiol Biomarkers Prev. 2006;15(11):2078-85.

9. Besson C, Canioni D, Lepage E, Pol S, Morel P, Lederlin P, et al. Characteristics and outcome of diffuse large B-cell lymphoma in hepatitis C virus-positive patients in LNH 93 and LNH 98 Groupe d'Etude des Lymphomes de l'Adulte programs. J Clin Oncol. 2006;24(6):953-60.

10. Chen TT, Chiu CF, Yang TY, Lin CC, Sargeant AM, Yeh SP, et al. Hepatitis C infection is associated with hepatic toxicity but does not compromise the survival of patients with diffuse large $B$ cell lymphoma treated with rituximab-based chemotherapy. Leuk Res. 2015;39(2):151-6.

11. Chen YY, Huang CE, Liang FW, Lu CH, Chen PT, Lee KD, et al. Prognostic impact of hepatitis $C$ virus infection in patients with diffuse large B-cell lymphoma treated with immunochemotherapy in the context of a novel prognostic index. Cancer Epidemiol. 2015;39(3):382-7.

12. Dlouhy I, Torrente MA, Lens S, Rovira J, Magnano L, Gine E, et al. Clinicobiological characteristics and outcome of hepatitis $C$ virus-positive patients with diffuse large B-cell lymphoma treated with immunochemotherapy. Ann Hematol. 2017;96(3):405-10.

13. Elbedewy TA, Elashtokhy HEA, Abd-Elsalam S, Suliman MA. Hepatitis C virus infection and treatment as independent prognostic factors in diffuse large B-cell lymphoma Egyptian patients. Curr Cancer Drug Targets. 2020;20(8):638-45

14. Ennishi D, Maeda Y, Niitsu N, Kojima M, Izutsu K, Takizawa J, et al. Hepatic toxicity and prognosis in hepatitis $C$ virus-infected patients with diffuse large B-cell lymphoma treated with rituximab-containing chemotherapy regimens: a Japanese multicenter analysis. Blood. 2010;116(24):5119-25.

15. Merli M, Visco C, Spina M, Luminari S, FerrettiW, Gotti M, et al. Outcome prediction of diffuse large B-cell lymphomas associated with hepatitis C virus infection: a study on behalf of the Fondazione Italiana Linfomi. Haematologica. 2014;99(3):489-96.

16. Park BB, Kim JS, Lee YY, Kang HJ, Ryoo BY, Kang JH, et al. Clinical characteristics and outcome for hepatitis C virus-positive diffuse large B-cell lymphoma. Leuk Lymphoma. 2008;49(1):88-94.

17. Hosry J, Mahale P, Turturro F, Miranda RN, Economides MP, Granwehr $\mathrm{BP}$, et al. Antiviral therapy improves overall survival in hepatitis C virusinfected patients who develop diffuse large B-cell lymphoma. Int J Cancer. 2016;139(11):2519-28.

18. Shimono J, Miyoshi H, Arakawa F, Yamada K, Sugio T, Miyawaki K, et al. Clinicopathological features of HCV-positive splenic diffuse large B cell lymphoma. Ann Hematol. 2019;98(5):1197-207.

19. Arcaini L, Vallisa D, Rattotti S, Ferretti W, Ferreri AJM, Bernuzzi P, et al. Antiviral treatment in patients with indolent B-cell lymphomas associated with HCV infection: a study of the Fondazione Italiana Linfomi. Ann Oncol. 2014;25(7):1404-10.

20. Michot JM, Canioni D, Driss H, Alric L, Cacoub P, Suarez F, et al. Antiviral therapy is associated with a better survival in patients with hepatitis $C$ virus and $B$-cell non-Hodgkin lymphomas, ANRS HC-13 lympho-C study. Am J Hematol. 2015;90(3):197-203.

21. Rattotti S, FerrettiW, Rusconi C, Rossi A, Fogazzi S, Baldini L, et al. Lymphomas associated with chronic hepatitis $\mathrm{C}$ virus infection: A prospective multicenter cohort study from the Rete Ematologica Lombarda (REL) clinical network. Hematol Oncol. 2019;37(2):160-7.

22. Zaky AH, Bakry R, El-sayed MI, Elwanis MA, Nabih O. Impact of treatmentrelated toxicity on outcome of HCV-positive diffuse large B-cell lymphoma in rituximab era. Hematology. 2014;19(7):412-6.

23. Stang A. Critical evaluation of the Newcastle-Ottawa scale for the assessment of the quality of nonrandomized studies in meta-analyses. Eur J Epidemiol. 2010;25(9):603-5.

24. Tierney JF, Stewart LA, Ghersi D, Burdett S, Sydes MR. Practical methods for incorporating summary time-to-event data into meta-analysis. Trials. 2007:8:16

25. Zhang MY, Chen FY, Zhong H. Meta-analysis of human leukocyte antigen genetic polymorphisms and susceptibility to chronic myelogenous leukemia in Chinese population. Leuk Res. 2011;35(12):1564-70.
26. Zhang MY, Miao L, Li YS, Hu GY. Meta-analysis of the methylenetetrahydrofolate reductase C677T polymorphism and susceptibility to Alzheimer's disease. Neurosci Res. 2010;68(2):142-50.

27. Zhang MY, Zhu GQ, Shi KQ, Zheng JN, Cheng Z, Zou ZL, et al. Systematic review with network meta-analysis: Comparative efficacy of oral nucleos(t) ide analogues for the prevention of chemotherapy-induced hepatitis B virus reactivation. Oncotarget. 2016;7(21):30642-58.

28. Zhang MY, Zhu GQ, Zheng JN, Cheng Z, Van Poucke S, Shi KQ, et al. Nucleos(t) ide analogues for preventing $\mathrm{HBV}$ reactivation in immunosuppressed patients with hematological malignancies: a network meta-analysis. Expert Rev Anti Infect Ther. 2017;15(5):503-13.

29. Nishikawa $H$, Tsudo M, Osaki Y. Clinical outcome in diffuse large B-cell lymphoma with hepatitis $C$ virus infection in the rituximab era: a single center experience. Oncol Rep. 2012;28(3):835-40.

30. Arcaini L, Burcheri S, Rossi A, Paulli M, Bruno R, Passamonti F, et al. Prevalence of HCV infection in nongastric marginal zone B-cell lymphoma of MALT. Ann Oncol. 2007;18(2):346-50.

31. Arcaini L, Lazzarino M, Colombo N, Burcheri S, Boveri E, Paulli M, et al. Splenic marginal zone lymphoma: a prognostic model for clinical use. Blood. 2006;107(12):4643-9.

32. Hosry J, Miranda RN, Samaniego F, Angelidakis G, Torres HA. Clinicopathologic characteristics of follicular lymphoma in hepatitis C virus-infected patients. Hematol Oncol. 2020;38(3):301-8.

33. Nesterova E, Tanaschuk E, Abdurakhmanov D, Gemdzhian E, Kravchenko S, Mangasarova Y, et al. Safe and effective treatment of follicular lymphoma in patients with HCV-infection. Hematol Oncol. 2020;38(4):604-6.

34. DeVita S, Sacco C, Sansonno D, Gloghini A, Dammacco F, Crovatto M, et al. Characterization of overt B-cell lymphomas in patients with hepatitis C virus infection. Blood. 1997;90(2):776-82.

35. Luppi M, Longo G, Ferrari MG, Barozzi P, Marasca R, Morselli M, et al. Clinico-pathological characterization of hepatitis C virus-related B-cell nonHodgkin's lymphomas without symptomatic cryoglobulinemia. Ann Oncol. 1998;9(5):495-8.

36. La Mura V, De Renzo A, Perna F, D'Agostino D, Masarone M, Romano M, et al. Antiviral therapy after complete response to chemotherapy could be efficacious in HCV-positive non-Hodgkin's lymphoma. J Hepatol. 2008;49(4):557-63.

37. Strianese D, Tranfa F, Finelli M, De Renzo A, Staibano S, Schiemer R, et al. Hepatitis C virus infection in ocular adnexal lymphomas. Arch Ophthalmol. 2010;128(10):1295-9.

38. Tajima K, Takahashi N, Ishizawa K, Murai K, Akagi T, Noji H, et al. Clinicopathological characteristics of malignant lymphoma in patients with hepatitis C virus infection in the Tohoku district in Eastern Japan. Leuk Lymphoma. 2017;58(6):1509-11.

39. Vallisa D, Bertè R, Rocca A, Civardi G, Giangregorio F, Ferrari B, et al. Association between hepatitis $C$ virus and non-Hodgkin's lymphoma, and effects of viral infection on histologic subtype and clinical course. Am J Med. 1999;106(5):556-60.

40. Persico M, Aglitti A, Caruso R, De Renzo A, Selleri C, Califano C, et al. Efficacy and safety of new direct antiviral agents in hepatitis $C$ virus-infected patients with diffuse large B-cell non-Hodgkin's lymphoma. Hepatology. 2018;67(1):48-55.

41. Salah-Eldin MA, Ebrahim MA, El-Sadda W. Clinical outcome of HCV-positive patients with diffuse large B-cell lymphoma treated with rituximab-based chemotherapy. Ann Hematol. 2014;93(11):1903-11.

42. World Health Organization. Global Hepatitis Report 2017. Geneva: World Health Organization; 2017.

43. Marcucci F, Mele A. Hepatitis viruses and non-Hodgkin lymphoma: epidemiology, mechanisms of tumorigenesis, and therapeutic opportunities. Blood. 2011;117(6):1792-8.

44. Weng WK, Levy S. Hepatitis C virus (HCV) and lymphomagenesis. Leuk Lymphoma. 2003;44(7):1113-20.

45. Küppers R, Dalla-Favera R. Mechanisms of chromosomal translocations in B cell lymphomas. Oncogene. 2001;20(40):5580-94.

46. Ferri C, Sebastiani M, Giuggioli D, Colaci M, Fallahi P, Piluso A, et al. Hepatitis C virus syndrome: a constellation of organ- and non-organ specific autoimmune disorders, B-cell non-Hodgkin's lymphoma, and cancer. World J Hepatol. 2015;7(3):327-43. 
47. Forghieri F, Luppi M, Barozzi P, Maffei R, Potenza L, Narni F, et al. Pathogenetic mechanisms of hepatitis C virus-induced B-cell lymphomagenesis. Clin Dev Immunol. 2012;2012:807351.

48. Peveling-Oberhag J, Arcaini L, Hansmann ML, Zeuzem S. Hepatitis C-associated B-cell non-Hodgkin lymphomas. Epidemiology, molecular signature and clinical management. J Hepatol. 2013;59(1):169-77.

49. Peveling-Oberhag J, Arcaini L, Bankov K, Zeuzem S, Herrmann E. The anti-lymphoma activity of antiviral therapy in HCV-associated B-cell nonHodgkin lymphomas: a meta-analysis. J Viral Hepat. 2016;23(7):536-44.

\section{Publisher's Note}

Springer Nature remains neutral with regard to jurisdictional claims in published maps and institutional affiliations.
Ready to submit your research? Choose BMC and benefit from:

- fast, convenient online submission

- thorough peer review by experienced researchers in your field

- rapid publication on acceptance

- support for research data, including large and complex data types

- gold Open Access which fosters wider collaboration and increased citations

- maximum visibility for your research: over 100M website views per year

At BMC, research is always in progress.

Learn more biomedcentral.com/submissions 